\title{
A Systematic Review of Sellar and Parasellar Brown Tumors: An Analysis of Clinical, Diagnostic, and Management Profiles
}

Short Title: Sellar and Parasellar Brown Tumors

\section{Authors}

Mohamedkazim M. Alwani, MD ${ }^{1,4}$

Gina N. Monaco, MD PhD ${ }^{2,4}$

Sydney M. Harmon, BSK ${ }^{4}$

Obi I. Nwosu, BS ${ }^{4}$

Alexander O. Vortmeyer, MD ${ }^{3,4}$

Troy D. Payner, MD ${ }^{2,4}$

Jonathan Ting, MD MS MBA ${ }^{1,2,4}$

\section{Author Affiliations}

${ }^{1}$ Department of Otolaryngology - Head and Neck Surgery

${ }^{2}$ Department of Neurological Surgery

${ }^{3}$ Department of Pathology and Laboratory Medicine

${ }^{4}$ Indiana University School of Medicine

\section{Corresponding Author}

Mohamedkazim M. Alwani, MD, Department of Otolaryngology - Head and Neck Surgery

Indiana University School of Medicine,

1120 W. Michigan Street, Suite 400, Indianapolis, IN 46202

Telephone: 317-529-4351 | Fax: 317-274-8285 | Email: malwani@iupui.edu

Word Count: 2,475

Key Words: Brown tumor, sellar tumor, parasellar tumor, sphenoid sinus tumor, hyperparathyroidism

Financial Disclosures: None | Authors disclose no conflict of interest

This is the author's manuscript of the article published in final edited form as:

Alwani, M. M., Monaco, G. N., Harmon, S. M., Nwosu, O. I., Vortmeyer, A. O., Payner, T. D., \& Ting, J. (2019). A Systematic Review of Sellar and Parasellar Brown Tumors: An Analysis of Clinical, Diagnostic, and Management Profiles. World Neurosurgery. https://doi.org/10.1016/j.wneu.2019.08.126 
Alwani, 2019

\section{INTRODUCTION}

Brown tumors are fibrovascular, expansile, lytic lesions that represent a tertiary manifestation of hyperparathyroidism. ${ }^{1} \quad$ With primary hyperparathyroidism, the autonomous release of parathyroid hormone (PTH) from a neoplastic, hyperplastic, or ectopic parathyroid nodule stimulates pathologic resorption of bone by osteoclasts leading to elevated serum calcium. On the other hand, secondary hyperparathyroidism occurs when chronically low serum calcium levels, for instance with calcium wasting in the setting of end-stage renal disease (ESRD), triggers a physiologically analogous elevation in PTH release with subsequent bone resorption in the attempt to restore serum calcium levels. The result of both primary and secondary hyperparathyroidism can be excessive bone resorption ${ }^{2,3}$ which may terminate with the formation of brown tumors. ${ }^{4,5}$

Though the incidence of brown tumors as a consequence of hyperparathyroidism is rare, ranging between $1.5 \%$ to $3 \%{ }^{3,6}$, most of the existing literature details the occurrence of these lesions in the facial, thoracic, pelvic, and spinal skeleton. ${ }^{4,5}$ Reports regarding involvement of the skull base, specifically the sellar and parasellar region, have remained exceedingly rare. ${ }^{3}$ The varied clinico-diagnostic profiles reported in the already scarce literature preclude a wellfounded consensus on the proper description, diagnostic workup, and/or management of these lesions. In this study, we report a patient with a histologically confirmed brown tumor in the clival region and provide a systematic review of past literature to evaluate clinical, diagnostic, and management trends.

\section{METHODS}

\section{Case Report}


Alwani, 2019

A 51-year-old male presented to the Emergency Department (ED) complaining of a few weeks of neck pain. The patient's medical history was notable for ESRD for which he had been receiving dialysis for 4.5 years. Review of systems was remarkable for dysphagia and a sensation of fullness in the tongue. Physical exam revealed left tongue atrophy and mild diplopia. His visit to the ED was complicated by hyperkalemia due to a missed dialysis regimen, and he consequently suffered pulseless cardiac arrest from which he was successfully resuscitated. During his subsequent workup, laboratory testing revealed an elevated PTH of $1,385 \mathrm{pg} / \mathrm{mL}$ (normal range: $10-65$ ) in the setting of normal serum calcium of $9.1 \mathrm{mg} / \mathrm{dL}$ (normal range: 8.4-10.2). At this juncture, a maxillofacial computed tomography (CT) scan without contrast was obtained and showed a lytic, expansile, and hyperdense mass involving the left clivus (Figure 1a-b). Magnetic resonance imaging (MRI) of the head with contrast showed a $4.2 \mathrm{~cm}$ by $1.5 \mathrm{~cm}$ enhancing mass of the left inferior clivus (Figure 1c).

A trans-nasal endoscopic approach was employed to resect the clival tumor. Histopathologic examination demonstrated multinucleated giant cells proliferating in a background of fibrovascular stroma with reactive bone formation (Figure 2a-c).

Following resection of the clival tumor, the patient was further evaluated for secondary hyperparathyroidism. Post-operative lab testing revealed normocalcemia in the setting of a persistently elevated PTH of $1,607 \mathrm{pg} / \mathrm{mL}$ and a single-photon emission computed tomography (SPECT) scan revealed parathyroid hyperplasia. The patient received a total parathyroidectomy for definitive surgical management of his secondary hyperparathyroidism. Post-operative PTH testing confirmed reversal of hyperparathyroidism. The patient was discharged on postoperative day 1 on an appropriate calcium supplementation regimen. At his 1-month postoperative follow up, the patient reported complete resolution of his symptoms. 


\section{Systematic Review}

We aimed to identify all full-text, peer-reviewed reports pertaining to brown tumors of the sellar/parasellar region. The Preferred Reporting Items for Systematic Reviews and MetaAnalyses (PRISMA) reporting standard ${ }^{7}$ served as a guideline for our review.

Eligibility criteria for inclusion and exclusion were determined prior to the literature search. Studies were included if they: (1) reported on sellar/parasellar brown tumors, (2) included key patient demographics and history findings, (3) provided key diagnostic findings including laboratory and imaging findings, (4) reported treatment modalities as well as follow-up data. Studies were excluded if they did not meet inclusion criteria and/or were: (1) a review of, or commentary on other pre-existing literature, (2) an editorial, (3) not written in English. Included articles were reviewed by two authors (M.A. and O.N.). On December 1, 2018, a thorough and comprehensive search of the PubMed, Ovid MEDLINE, Scopus, and Google Scholar databases was conducted to identify eligible studies. The search terms used included "brown tumors", "sellar brown tumor", "parasellar brown tumor", and "clival brown tumor".

The following information, when available, was extracted from the included reports: author, year of publication, patient demographics, character and duration of symptoms, abnormal lab values, imaging characteristics, histopathologic descriptions, management modalities, and follow-up data.

\section{RESULTS}

Study Selection 
Alwani, 2019

A summary of the PRISMA protocol is provided in Figure 3. A systematic search of PubMed, MEDLINE, Scopus, and Google Scholar databases yielded a total of 118 articles. Thirty-two (32) duplicate articles were removed leaving 86 articles eligible for preliminary title and abstract screening. After screening, 56 articles did not meet inclusion criteria and were thus excluded. The remaining 30 articles were subjected to a comprehensive full-text review. Subsequently, only 7 articles were eligible for final inclusion in the systematic review ${ }^{3,6,8-12}$. All frequency results are based on a total of 8 sellar/parasellar brown tumor cases ( 7 previously documented cases in addition to the current case report).

\section{Demographics and Clinical Findings}

The publication dates ranged from 1986 - 2014. A summary of the demographic and clinical profile of each reported case is provided in Table 1. All reported cases involved female patients, with the current reported case emerging as the only documented case of a sellar/parasellar brown tumor in a male patient. Patient age ranged from 18 to 59 years with a mean of 42.75 years. Five of eight cases provided a past medical history $(62.5 \%)$, four of which were notable for ESRD (80\%). Reported symptoms included visual disturbances such as decreased visual acuity or diplopia $(n=6)$, headache $(n=5)$, fatigue $(n=3)$, nausea/vomiting $(n=2)$, chest pain $(n=1)$, neck pain $(n=1)$, and dysphagia $(n=1)$. Duration of symptoms ranged from 1 day to 24 months with a mean of 4.14 months. All reports provided a description of laboratory values. Laboratory findings included elevated alkaline phosphatase (ALP) $(n=7)$, elevated PTH $(n=6)$, hypercalcemia $(n=5)$, azotemia $(n=3)$, hypophosphatemia $(n=2)$, hypocalcemia $(n=2)$, anemia $(n=2)$, hyperphosphatemia $(n=1)$, and hyperchloremia $(n=1)$. A summary of lab findings is also provided in Table 1.

Imaging and Histopathologic Findings 
Alwani, 2019

Reported preoperative imaging modalities included maxillofacial CT $(n=6)$ and MRI head/neck $(n=6)$, and skull radiographs $(n=2)$. In all 6 cases where CT findings were provided, the sellar/parasellar lesions were noted to be expansile and lytic. Contrast enhancement was noted on 5 MRIs (83.3\%) and hyperintensity was reported on T2-weighted (T2W) imaging in 4 MRIs (66.7\%). Imaging modalities employed in concurrent workup of hyperparathyroidism included parathyroid ultrasound $(n=2)$, parathyroid scintigraphy $(n=2), M R I$ of the neck $(n=2)$, bone scintigraphy $(n=1)$, and SPECT scan $(n=1)$. Histopathologic findings were reported in 7 of the reports $(87.5 \%)$. Similar histology of multinucleated giant cells surrounded loose fibrovascular stroma was noted in all of these cases (as demonstrated in Figure 2). All imaging and histopathologic findings are detailed in Table 2.

\section{Tumor Characteristics, Management, and Follow-Up Status}

Tumor characteristics (location and size) are summarized in Table 1. All 8 reports documented the location of the brown tumor. Tumor locations reported included the sphenoid bone $(n=7)$, occipital bone $(n=2)$, parietal bone $(n=1)$, and clivus $(n=1)$. Two cases reported involvement of anatomic sites in addition to the skull base i.e. cervical spine and multiple lytic rib lesions, respectively. Tumor size was reported in 4 of the 8 case reports (50\%) with a mean size of $3.1 \mathrm{x}$ $3.0 \times 2.5 \mathrm{~cm}$.

Surgical management was reported in all 8 cases. Extirpation of the sellar/parasellar lesion was documented in 4 of the 8 cases $(50 \%)$. A trans-nasal approach was employed in all 4 cases. The remainder received only endocrine surgery for management of hyperparathyroidism. Management information is summarized in Table 1.

Length of follow-up was documented in six of eight cases $(75 \%)$ with a mean follow-up time of 1.3 years and a range of 0.5 to 3 years. All patients who received trans-nasal resection of their 
Alwani, 2019

sellar/parasellar lesions exhibited complete or significant symptom resolution. Symptom recurrence was noted in 1 case reported by Schweitzer et al. ${ }^{9}$ Surgical complications related to endocrine surgery were noted in 2 cases $^{11,12}$, whereby patients experienced persistent hypocalcemia following parathyroidectomy. Both patients were successfully treated with calcium and vitamin D supplementation. No surgical complications from trans-nasal resections were reported.

\section{DISCUSSION}

Brown tumors are osteolytic, expansile lesions resulting from hyperparathyroidism that represent a tertiary fibro-osseous remodeling reaction rather than a true neoplasm. ${ }^{6}$ Excess PTH in hyperparathyroidism drives osteoclastic and osteoblastic processes that subsequently cause bony resorption and fibro-osseous remodeling of the cortex and marrow. ${ }^{8}$ Although these lesions were first described by Gerhard Engle in $1864^{13}$, their association with hyperparathyroidism was reported later in 1905 by Askanazy. ${ }^{3}$ However, this relation between brown tumors and hyperparathyroidism has been infrequently reported after the advent of biochemical testing for hypercalcemia and hyperparathyroidism. Since such testing has allowed for early detection and management of hyperparathyroidism, and given that brown tumors progress slowly and manifest late in the natural history of hyperparathyroidism, the overall incidence has decreased secondary to early intervention for hyperparathyroidism. ${ }^{11}$

Studies have found that the incidence of brown tumors is higher in primary hyperparathyroidism (usually caused by parathyroid adenomas or hyperplasia) at $3 \%$ to $5 \%$, than in secondary hyperparathyroidism (usually caused by chronic renal failure or vitamin D deficiency) at $1.5 \%$ to $1.7 \% .^{3,6}$ As was the case with the patient presented in our study, the authors agree with the hypothesis put forward by Kanaan et al suggesting that perhaps an increase in incidence of 
Alwani, 2019

brown tumors from secondary hyperparathyroidism may now be observed given the increased longevity of patients with ESRD due to improved dialysis technology and services. ${ }^{3}$

Brown tumors primarily occur in the mandible, clavicle, ribs, pelvis, and long bones such as the femur. ${ }^{6,12}$ Although studies have reported involvement of the maxilla, palate, temporal bone, nasal cavity, and orbital bone in the craniofacial region, reports of sellar/parasellar brown tumors remain exceedingly rare. ${ }^{6}$ Interestingly, and as demonstrated by our results, these limited reports of sellar/parasellar brown tumors show a tendency to occur in females $(n=7,87.5 \%)$, perhaps due to the higher incidence of hyperparathyroidism in females as compared to males. ${ }^{14,15}$

The clinical presentation of brown tumors varies depending on the anatomical site of the lesion. Sellar/parasellar brown tumors most commonly present with headaches and/or visual changes, but other symptoms including nausea, vomiting, and focal neurological deficits have been reported. ${ }^{3,6,8-12}$ Histologically, brown tumors consist of multinucleated osteoclast-like giant cells in a spindle cell connective tissue stromal background. Large areas of bone resorption, hemorrhagic foci, and multifocal hemosiderin deposits represent degenerative changes that commonly occur in brown tumors. ${ }^{6,8,12}$ Accumulation of hemosiderin imparts a reddish-brown tint to the lesions, giving the lesions their name (i.e. brown tumors). ${ }^{3}$

Key differential diagnoses for sellar/parasellar lesions often include invasive pituitary tumors, fibrous dysplasia, carcinomas, chordomas, chondrosarcomas, and neuroendocrine tumors. ${ }^{3,16}$ The rarity of sellar/parasellar brown tumors generates a significant potential for misdiagnosis. Even at a histological level, the presence of giant cells necessitates a great deal of diagnostic astuteness to differentiate brown tumors of hyperparathyroidism from giant-cell reparative granulomas and true giant-cell tumors. ${ }^{6}$ 
Alwani, 2019

Although the appearance of sellar/parasellar brown tumors on radiographs has not been classified, brown tumors in other anatomic areas classically exhibit widespread subperiosteal bone resorption. ${ }^{10}$ This is consistent with the case reported by Erem et al that documented diffuse osteopenia with salt-and-pepper stippling seen on skull x-ray. ${ }^{8}$ Radiographic findings were also reported by Takeshita et al where opacification of the sphenoid sinus was noted. ${ }^{6}$ On CT imaging, sellar/parasellar brown tumors appear as lytic, expansile, and enhancing lesions, similar to brown tumors occurring in other regions of the body. The lytic and expansile nature of these lesions suggests a slow-growing process. ${ }^{6}$ Although varying MR imaging characteristics have been reported for sellar/parasellar brown tumors, our review revealed a trend where by these tumors were often hyperintense on T2W and enhanced with contrast. ${ }^{6,8,10,12}$ Heterogeneity was often reported on T2W images given the heterogenous pathological background these lesions consisting of hemorrhagic foci, hemosiderin deposits, and other cystic components.

The exceedingly rare nature of sellar/parasellar brown tumors has precluded the establishment of definitive therapeutic guidelines. Previous studies have advocated that the first step in management is to treat (either medically or surgically) the primary underlying endocrine etiology with the ultimate goal of achieving normalized lab values with ensuing spontaneous regression of brown tumors. However, the regression response with this strategy in sellar/parasellar lesion remains unclear, with reports showing minimal response ${ }^{12}$ or even progression. ${ }^{9}$ Therefore, in cases of larger brown tumors that are persistent and unresponsive to endocrine therapy, or in cases where acute deficits are present and lasting complications are possible, acute surgical decompression is indicated and favored. Our review of literature demonstrates that surgical extirpation yields favorable outcomes with complete symptom resolution noted in all patients who received surgical excision. 
Alwani, 2019

\section{CONCLUSION}

Sellar/parasellar brown tumors are a rare, tertiary manifestation of a common disease entity (i.e. hyperparathyroidism), and therefore can be elusive to diagnose. Appropriate, timely diagnosis (and consequent management) often requires a high index of clinical suspicion augmented by a complete workup including biochemical testing, imaging, and histopathologic analysis. Surgical removal of the skull base lesion is favored in the event that the lesion is causing compressive symptoms, or if it is unresponsive to management of hyperparathyroidism. 


\section{REFERENCE}

1. Misiorowski W, Czajka-Oraniec I, Kochman M, Zgliczyński W, Bilezikian JP. Osteitis fibrosa cystica-a forgotten radiological feature of primary hyperparathyroidism. Endocrine. 2017;58(2):380-385. doi:10.1007/s12020-017-1414-2

2. Benmoussa L, Renoux M, Radoï L. Oral Manifestations of Chronic Renal Failure Complicating a Systemic Genetic Disease: Diagnostic Dilemma. Case Report and Literature Review. J Oral Maxillofac Surg. 2015;73(11):2142-2148. doi:10.1016/j.joms.2015.05.029

3. Kanaan I, Ahmed M, Rifai A, Alwatban J. Sphenoid sinus brown tumor of secondary hyperparathyroidism: case report. Neurosurgery. 1998;42(6):1374-1377. http://www.ncbi.nlm.nih.gov/pubmed/9632199. Accessed May 10, 2019.

4. Queiroz IV, Queiroz SP, Medeiros R, Ribeiro RB, Crusoé-Rebello IM, Leão JC. Brown tumor of secondary hyperparathyroidism: surgical approach and clinical outcome. Oral Maxillofac Surg. 2016;20(4):435-439. doi:10.1007/s10006-016-0575-0

5. Selvi F, Cakarer S, Tanakol R, Guler S, Keskin C. Brown tumour of the maxilla and mandible: a rare complication of tertiary hyperparathyroidism. Dentomaxillofacial Radiol. 2009;38(1):53-58. doi:10.1259/dmfr/81694583

6. Takeshita T, Tanaka H, Harasawa A, Kaminaga T, Imamura T, Furui S. Brown tumor of the sphenoid sinus in a patient with secondary hyperparathyroidism: CT and MR imaging findings. Radiat Med. 22(4):265-268. http://www.ncbi.nlm.nih.gov/pubmed/15468948. Accessed May 10, 2019.

7. Liberati A, Altman DG, Tetzlaff J, et al. The PRISMA statement for reporting systematic reviews and meta-analyses of studies that evaluate healthcare interventions: explanation and elaboration. BMJ. 2009;339(jul21 1):b2700. doi:10.1136/bmj.b2700

8. Erem C, Hacihasanoglu A, Cinel A, et al. Sphenoid sinus brown tumor, a mass lesion of occipital bone and hypercalcemia: an unusual presentation of primary 
hyperparathyroidism. J Endocrinol Invest. 2004;27(4):366-369.

http://www.ncbi.nlm.nih.gov/pubmed/15233558. Accessed May 10, 2019.

9. Schweitzer VG, Thompson NW, McClatchey KD. Sphenoid sinus brown tumor, hypercalcemia, and blindness: an unusual presentation of primary hyperparathyroidism. Head Neck Surg. 8(5):379-386. http://www.ncbi.nlm.nih.gov/pubmed/3793483. Accessed May 10, 2019.

10. Yilmazlar S, Arslan E, Aksoy K, Tolunay S. Sellar-Parasellar Brown Tumor: Case Report and Review of Literature. Skull Base. 2004;14(3):163-168. doi:10.1055/s-2004-832261

11. Loya-Solís A, Mendoza-García A, Ceceñas-Falcón L, Rodríguez-Gutiérrez R. Sphenoid Brown Tumor Associated with a Parathyroid Carcinoma. Case Rep Endocrinol. 2014;2014:1-5. doi:10.1155/2014/837204

12. Lando HM. A case report of a patient with hyperparathyroidism and presumed sellar/parasellar brown tumor. Endocr Regul. 2012;46(1):31-36. http://www.ncbi.nlm.nih.gov/pubmed/22329820. Accessed May 10, 2019.

13. Zhang HL. Multiple brown tumors: A diagnostic dilemma. Endocrinologist. 2010. doi:10.1097/TEN.0b013e3181e94743

14. Yeh MW, Ituarte PHG, Zhou HC, et al. Incidence and prevalence of primary hyperparathyroidism in a racially mixed population. J Clin Endocrinol Metab. 2013. doi:10.1210/jc.2012-4022

15. Kidney Disease Statistics for the United States | NIDDK. National Institute of Diabetes and Digestive and Kidney Diseases.

16. DeMonte F, Ginsberg LE, Clayman GL. Primary malignant tumors of the sphenoidal sinus. Neurosurgery. 2000. doi:10.1097/00006123-200005000-00012 


\section{FIGURE LEGENDS}

Figure 1A: Axial maxillofacial CT without contrast demonstrating left clival brown tumor (arrow)

Figure 1B: Sagittal maxillofacial CT without contrast demonstrating clival brown tumor (arrow)

Figure 1C: Axial, T1-weighted, post-contrast MRI showing an enhancing left clival mass (arrow)

Figure 2. H\&E-stained sections reveal focally preserved osteoid and large areas of bone resorption $(\mathbf{A}, 100 x$, measuring bar $=100 \mu \mathrm{m})$ characterized by multinucleated osteoclast-like giant cells and fibroblasts (B, 400x, measuring bar $=50 \mu \mathrm{m}$ ). Multifocal hemosiderin depositions (C, 400x, measuring bar $=50 \mu \mathrm{m}$ ) represent degenerative changes that commonly occur in brown tumors.

Figure 3. Preferred Reporting Items for Systematic Reviews and Meta-Analyses (PRISMA) flow diagram of article identification and selection. 
Table 1. Summary of patient information, medical and surgical management, and follow-up status.

\begin{tabular}{|c|c|c|c|c|c|c|c|c|c|}
\hline Study & Age/Sex & Symptoms (Duration) & Abnormal lab values & $\begin{array}{l}\text { Primary } \\
\text { disturbance }\end{array}$ & $\begin{array}{l}\text { Tumor } \\
\text { location }\end{array}$ & $\begin{array}{l}\text { Tumor size } \\
\text { (cm) }\end{array}$ & $\begin{array}{l}\text { Medical } \\
\text { management }\end{array}$ & Surgical Management & Follow-up (Duration) \\
\hline $\begin{array}{l}\text { Schweitzer et } \\
\text { al. } 1986\end{array}$ & $46 / \mathrm{F}$ & $\begin{array}{l}\text { Left frontal \& retro- } \\
\text { orbital headaches }(6 \mathrm{mo}) \text {; } \\
\text { Left diplopia and vision } \\
\text { loss (1mo) }\end{array}$ & $\begin{array}{l}\text { Hypercalcemia, } \\
\text { elevated ALP }\end{array}$ & $\begin{array}{l}10 \text { HPT due to } \\
\text { parathyroid } \\
\text { adenoma }\end{array}$ & $\begin{array}{l}\text { Sphenoid } \\
\text { sinus }\end{array}$ & NA & None & $\begin{array}{l}\text { Resection of parathyroid } \\
\text { adenoma following } \\
\text { endoscopic and open } \\
\text { biopsies of sellar lesion. }\end{array}$ & $\begin{array}{l}\text { Despite normocalcemia, } \\
\text { patient reported new-onset } \\
\text { disequilibrium, tinnitus, and } \\
\text { hearing loss in left ear. } \\
\text { CT and histopathology } \\
\text { revealed progression of BT } \\
\text { (16mo) }\end{array}$ \\
\hline $\begin{array}{l}\text { Kanaan et al. } \\
1998\end{array}$ & $21 / \mathrm{F}$ & $\begin{array}{l}\text { Headache, nausea, } \\
\text { vision impairment }(4 \mathrm{mo})\end{array}$ & $\begin{array}{l}\text { Hypocalcemia, } \\
\text { hypochloremia, } \\
\text { hyperphosphatemia, } \\
\text { elevated ALP }\end{array}$ & $\begin{array}{l}\text { 20 HPT due to } \\
\text { ESRD }\end{array}$ & $\begin{array}{l}\text { Sphenoid } \\
\text { sinus }\end{array}$ & NA & None & $\begin{array}{l}\text { TNR of sellar lesion (1 } \\
\text { month after decompression } \\
\text { of lesion through a right } \\
\text { lateral rhinotomy and } \\
\text { external ethmoidectomy) }\end{array}$ & $\begin{array}{l}\text { Minor post-op changes seen } \\
\text { on MRI with dramatically } \\
\text { improved vision ( } 36 \mathrm{mo})\end{array}$ \\
\hline $\begin{array}{l}\text { Erem et al. } \\
2004\end{array}$ & $47 / \mathrm{F}$ & $\begin{array}{l}\text { Headache, dizziness, } \\
\text { diffuse arthralgia \& } \\
\text { fatigue ( } 24 \mathrm{mo}) ; \\
\text { Nausea \& vomiting } \\
\text { (6mo) }\end{array}$ & $\begin{array}{l}\text { Anemia, } \\
\text { elevated BUN \& Cr, } \\
\text { hypercalcemia, elevated ALP, } \\
\text { elevated iPTH }\end{array}$ & $\begin{array}{l}10 \text { HPT due to } \\
\text { parathyroid } \\
\text { adenoma }\end{array}$ & $\begin{array}{l}\text { Sphenoid } \\
\text { sinus and } \\
\text { occipital } \\
\text { bone }\end{array}$ & $\begin{array}{l}\text { Sphenoid: } \\
5 \times 3.5 \times 3.5 \mathrm{~cm} \\
\text { Occipital: } \\
3 \times 2 \times 2 \mathrm{~cm}\end{array}$ & None & $\begin{array}{l}\text { Resection of right-inferior } \\
\text { parathyroid adenoma }\end{array}$ & $\begin{array}{l}\text { Complete symptom resolution } \\
\text { with normalized labs except an } \\
\text { elevated ALP (12mo) }\end{array}$ \\
\hline $\begin{array}{l}\text { Takeshita et al. } \\
2004\end{array}$ & $47 / \mathrm{F}$ & $\begin{array}{l}\text { Headache, left ptosis, } \\
\text { and worsening right } \\
\text { diplopia ( } 3 \text { days) }\end{array}$ & $\begin{array}{l}\text { Elevated BUN and } \mathrm{Cr} \text {, } \\
\text { hypocalcemia, } \\
\text { elevated ALP, elevated IPTH }\end{array}$ & $\begin{array}{l}\text { 20 HPT due to } \\
\text { ESRD }\end{array}$ & $\begin{array}{l}\text { Sphenoid } \\
\text { sinus }\end{array}$ & NA & None & TNR of sellar lesion & Dramatic symptom relief (NA) \\
\hline $\begin{array}{l}\text { Yilmazlar et al. } \\
2004\end{array}$ & $59 / \mathrm{F}$ & $\begin{array}{l}\text { Headache, impaired } \\
\text { vision in the right eye, } \\
\text { and diplopia }(5 \mathrm{mo}) ; \\
\text { Reduced vision and } \\
\text { ptosis in left eye (1mo) }\end{array}$ & $\begin{array}{l}\text { Hypercalcemia, } \\
\text { hypophosphatemia, elevated } \\
\text { ALP, elevated PTH }\end{array}$ & $\begin{array}{l}10 \text { HPT due to } \\
\text { parathyroid } \\
\text { adenoma }\end{array}$ & $\begin{array}{l}\text { Sphenoid } \\
\text { sinus and } \\
\text { parietal } \\
\text { bone }\end{array}$ & $\begin{array}{l}\text { Parietal: } \\
1 \times 2 \mathrm{~cm} \\
\text { Sphenoid: } \\
\text { NA }\end{array}$ & None & TNR of sellar lesion & $\begin{array}{l}\text { Improved vision with } \\
\text { normalized labs ( } 8 \mathrm{mo})\end{array}$ \\
\hline Lando HM 2012 & $18 / \mathrm{F}$ & Chest pain (NA) & $\begin{array}{l}\text { Hypercalcemia, elevated } \\
\text { ALP, elevated PTH }\end{array}$ & $\begin{array}{l}10 \text { HPT due to } \\
\text { parathyroid } \\
\text { adenoma }\end{array}$ & $\begin{array}{l}\text { Sphenoid } \\
\text { sinus }\end{array}$ & $3.4 \times 4.7 \mathrm{~cm}$ & None & $\begin{array}{l}\text { Resection of parathyroid } \\
\text { adenoma }\end{array}$ & $\begin{array}{l}\text { Marginal regression of } \\
\text { sphenoidal lesion to } 3 \times 4 \mathrm{~cm} \\
(18 \mathrm{mo})\end{array}$ \\
\hline $\begin{array}{l}\text { Loya-Solis et al. } \\
2014\end{array}$ & $53 / \mathrm{F}$ & $\begin{array}{l}\text { Bitemporal hemianopsia } \\
\text { and diplopia, fatigue, } \\
\text { generalized weakness, } \\
\text { and somnolence }(2 \mathrm{mo})\end{array}$ & $\begin{array}{l}\text { Anemia, hypercalcemia, } \\
\text { hypophosphatemia, } \\
\text { hypomagnesemia, elevated } \\
\text { ALP, elevated PTH }\end{array}$ & $\begin{array}{l}\text { 10 HPT due to } \\
\text { parathyroid } \\
\text { carcinoma }\end{array}$ & $\begin{array}{l}\text { Sphenoid } \\
\text { sinus }\end{array}$ & $3 \times 3 \times 2 \mathrm{~cm}$ & $\begin{array}{l}\text { Hydration, } \\
\text { furosemide, } \\
\text { zoledronate }\end{array}$ & $\begin{array}{l}\text { Left hemithyroidectomy \& } \\
\text { ipsilateral } \\
\text { parathyroidectomy }\end{array}$ & $\begin{array}{l}\text { Improved visual fields with } \\
\text { normalized labs }(6 \mathrm{mo})\end{array}$ \\
\hline $\begin{array}{l}\text { Present case, } \\
2018\end{array}$ & $51 / \mathrm{M}$ & $\begin{array}{l}\text { Neck pain, dysphagia, } \\
\text { and sensation of fullness } \\
\text { of tongue, } 1 \text { month }\end{array}$ & Elevated PTH & $\begin{array}{l}\text { 20 HPT due to } \\
\text { ESRD }\end{array}$ & $\begin{array}{l}\text { Left clivus \& } \\
\text { occipital } \\
\text { condyle }\end{array}$ & $2.9 \times 1.6 \mathrm{~cm}$ & None & $\begin{array}{l}\text { TNR of clival lesion followed } \\
\text { by total parathyroidectomy } \\
\text { with auto-transplantation }\end{array}$ & $\begin{array}{l}\text { Complete symptom resolution, } \\
\text { with normalized labs }(6 \mathrm{mo})\end{array}$ \\
\hline
\end{tabular}

ALP, alkaline phosphatase; BT, brown tumor; BUN, blood urea nitrogen; $\mathrm{Cr}$, creatinine; ESRD, end-stage renal disease; F, female; HPT, hyperparathyroidism; iPTH, intact parathyroid hormone; NA, not available; PTH, parathyroid hormone; TNR, trans-nasal resection 
Table 2. Summary of imaging, gross, and histopathologic findings.

\begin{tabular}{|c|c|c|c|c|c|}
\hline Study & XR & CT & MRI & Histopathology & Parathyroid imaging \\
\hline $\begin{array}{l}\text { Schweitzer et } \\
\text { al. } 1986\end{array}$ & NA & $\begin{array}{l}\text { Expansile, lytic heterogenous } \\
\text { sellar mass with remodeling of } \\
\text { surrounding bone and } \\
\text { involvement of cavernous sinus }\end{array}$ & NA & $\begin{array}{l}\text { Diffuse fibrosis with mixed chronic } \\
\text { inflammatory infiltrate }\end{array}$ & NA \\
\hline $\begin{array}{l}\text { Kanaan et al. } \\
1998\end{array}$ & NA & $\begin{array}{l}\text { Expansile, lytic sellar mass with } \\
\text { remodeling of surrounding bone } \\
\text { and involvement of right orbit } \\
\text { and posterior ethmoid sinus }\end{array}$ & $\begin{array}{l}\text { Lesion morphology same as CT } \\
\text { T1: Heterogenous hyperintense foci } \\
\text { T2: Heterogenous hyperintense foci }\end{array}$ & $\begin{array}{l}\text { Regenerative bone surrounded by } \\
\text { fibrovascular stroma and } \\
\text { multinucleated giant cells }\end{array}$ & NA \\
\hline $\begin{array}{l}\text { Erem et al. } \\
2004\end{array}$ & $\begin{array}{l}\text { Diffuse osteopenia } \\
\text { and subperiosteal } \\
\text { resorption, salt-and- } \\
\text { pepper stippling in the } \\
\text { skull }\end{array}$ & NA & $\begin{array}{l}\text { Expansile, lytic sellar mass eroding into } \\
\text { medial wall of right orbit and posterior } \\
\text { ethmoid sinus } \\
\text { T1: Contrast enhancing } \\
\text { T2: Hyperintense }\end{array}$ & $\begin{array}{l}\text { Multinucleated giant cells } \\
\text { surrounded by fibrovascular } \\
\text { stroma with focal hemorrhages } \\
\text { and hemosiderin-laden } \\
\text { macrophages as well as focal sites } \\
\text { of reactive woven bone formation }\end{array}$ & $\begin{array}{l}\text { Parathyroid } \mathrm{U} / \mathrm{S} \text { revealed a } 26 \times 18 \mathrm{~mm} \text { heterogenous mass } \\
\text { at posterior-inferior right thyroid lobe } \\
\text { MRI of neck showed hyperintensity in the same area } \\
\text { Histopathologic examination of resected mass revealed } \\
\text { parathyroid adenoma }\end{array}$ \\
\hline $\begin{array}{l}\text { Takeshita et } \\
\text { al. } 2004\end{array}$ & $\begin{array}{l}\text { Opacification of the } \\
\text { sphenoid sinus }\end{array}$ & $\begin{array}{l}\text { Expansile, lytic heterogenous } \\
\text { sellar mass with remodeling of } \\
\text { surrounding bone }\end{array}$ & $\begin{array}{l}\text { Lesion morphology same as CT } \\
\text { T1: Isointense, contrast enhancing } \\
\text { T2: Heterogeneously hyperintense }\end{array}$ & $\begin{array}{l}\text { Multinucleated giant cells, loose } \\
\text { fibrous stroma with spindle-shaped } \\
\text { mononucleated cells, focal } \\
\text { hemorrhage and hemosiderin } \\
\text { deposition }\end{array}$ & NA \\
\hline $\begin{array}{l}\text { Yilmazlar et al. } \\
2004\end{array}$ & NA & $\begin{array}{l}\text { Expansile, lytic sellar mass with } \\
\text { remodeling of surrounding bone } \\
\text { and involvement of posterior } \\
\text { ethmoid sinus; } \\
\text { Distinct lytic lesion in noted in } \\
\text { right parietal bone }\end{array}$ & $\begin{array}{l}\text { Lesion morphology same as CT } \\
\text { T1: Isointense, contrast enhancing } \\
\text { T2: Hyperintense, contrast enhancing }\end{array}$ & $\begin{array}{l}\text { Central osteoclasts with focal areas } \\
\text { of fibroblasts and hemorrhage }\end{array}$ & $\begin{array}{l}\text { MRI of neck revealed a T1 hypointense, T2 hyperintense left } \\
\text { inferior parathyroid lesion; } \\
\text { Parathyroid scintigraphy revealed an adenoma in the same } \\
\text { area; } \\
\text { Bone scintigraphy displayed increased activity in proximal } \\
\text { right radius, parietooccipital area, and left tibia }\end{array}$ \\
\hline $\begin{array}{l}\text { Lando HM } \\
2012\end{array}$ & NA & NA & $\begin{array}{l}\text { Sellar mass with involvement of optic } \\
\text { chiasm and cavernous sinus } \\
\text { T1: NA } \\
\text { T2: "Markedly dark", contrast enhancing }\end{array}$ & NA & $\begin{array}{l}\text { Parathyroid } \mathrm{U} / \mathrm{S} \text { revealed a heterogenous parathyroid mass; } \\
\text { Histopathologic examination revealed parathyroid adenoma }\end{array}$ \\
\hline $\begin{array}{l}\text { Loya-Solis et } \\
\text { al. } 2014\end{array}$ & NA & $\begin{array}{l}\text { Expansile, Iytic heterogenous } \\
\text { sellar mass with remodeling of } \\
\text { surrounding bone and erosion } \\
\text { the sphenoid corpus }\end{array}$ & NA & $\begin{array}{l}\text { Multinucleated giant cells in } \\
\text { fibrous stroma with hemosiderin } \\
\text { deposition }\end{array}$ & $\begin{array}{l}\text { Parathyroid } \mathrm{U} / \mathrm{S} \text { and scintigraphy revealed enlarged right } \\
\text { inferior parathyroid gland and hyperfunction; } \\
\text { Histopathologic examination of resected parathyroid gland } \\
\text { was diagnostic of parathyroid carcinoma }\end{array}$ \\
\hline $\begin{array}{l}\text { Present case, } \\
2018\end{array}$ & None & $\begin{array}{l}\text { Expansile, Iytic heterogenous } \\
\text { sellar mass with remodeling of } \\
\text { surrounding bone with } \\
\text { involvement occipital condyle }\end{array}$ & $\begin{array}{l}\text { T1: hypointense, contrast enhancing } \\
\text { T2: hyperintense }\end{array}$ & $\begin{array}{l}\text { Giant cell proliferation and } \\
\text { hemosiderin deposits in a spindle } \\
\text { stromal connective tissue } \\
\text { background }\end{array}$ & SPECT scanning revealed parathyroid hyperplasia \\
\hline
\end{tabular}

CT, computed tomography; MRI, magnetic resonance imaging; NA, not available; SPECT, single-photon emission computed tomography; U/S, ultra-sound 
Figure 1A: Axial maxillofacial CT without contrast demonstrating left clival brown tumor (arrow)

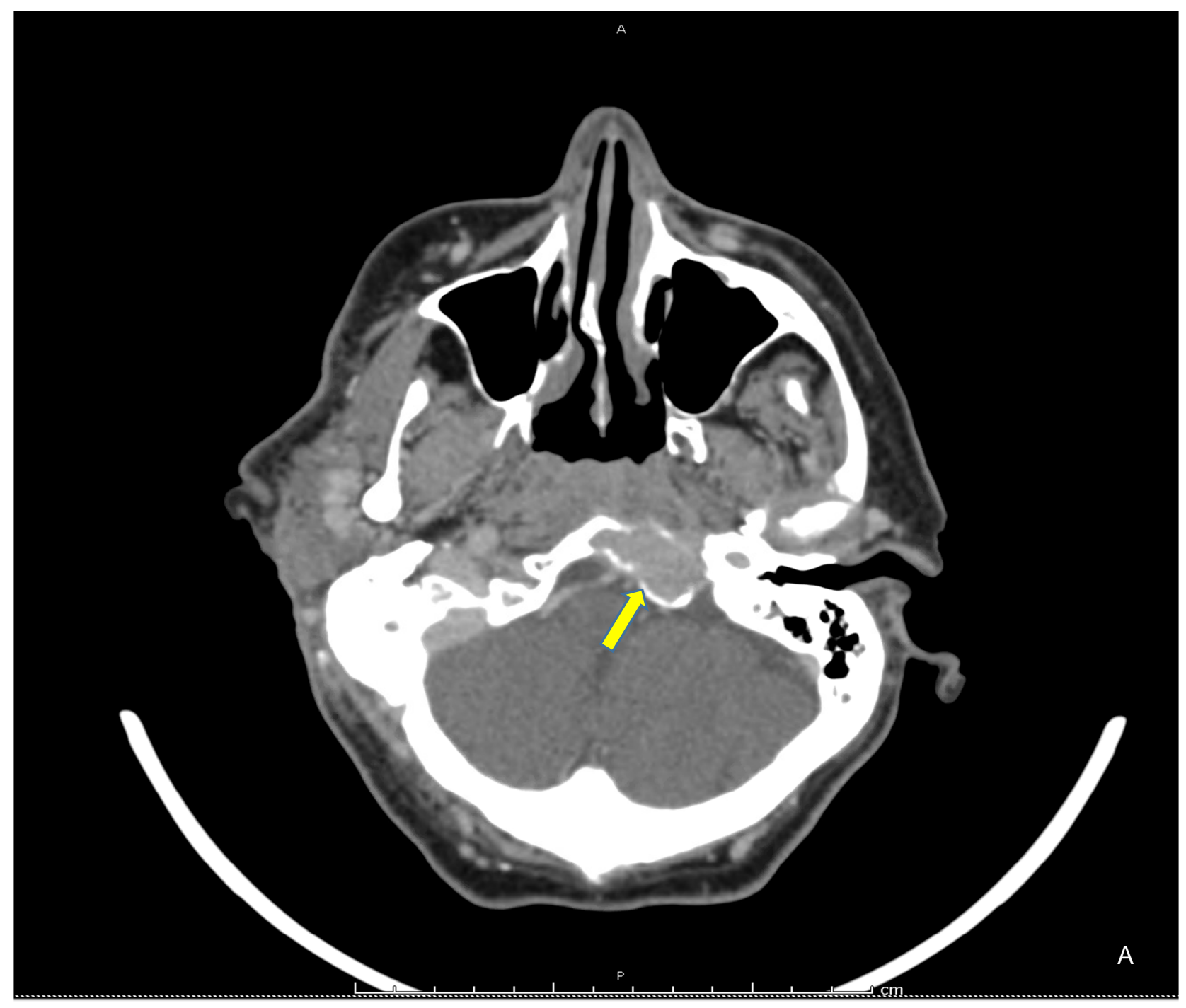


Figure 1B: Sagittal maxillofacial CT without contrast demonstrating clival brown tumor (arrow)

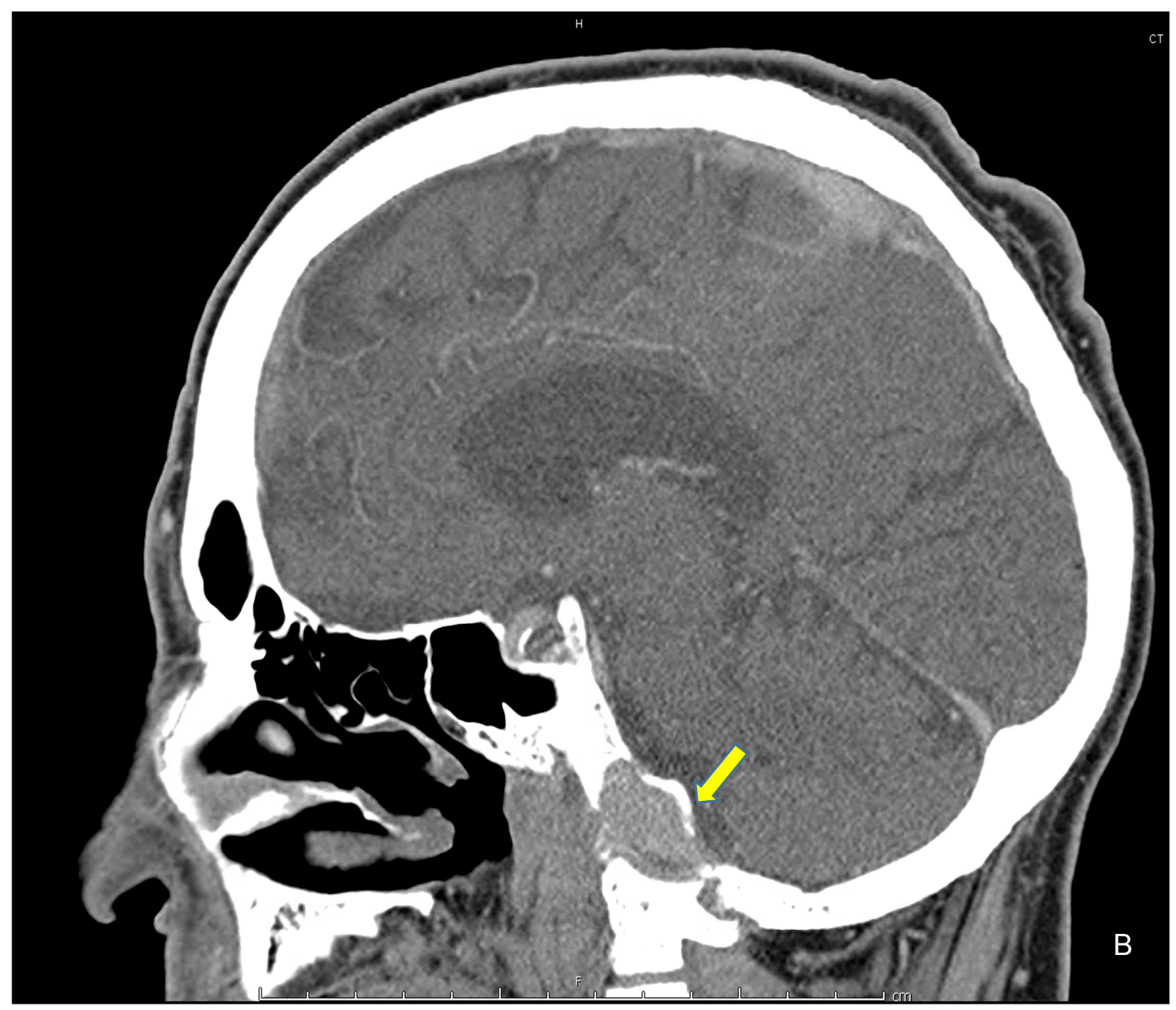


Figure 1C: Axial, T1-weighted, post-contrast MRI showing an enhancing left clival mass (arrow)

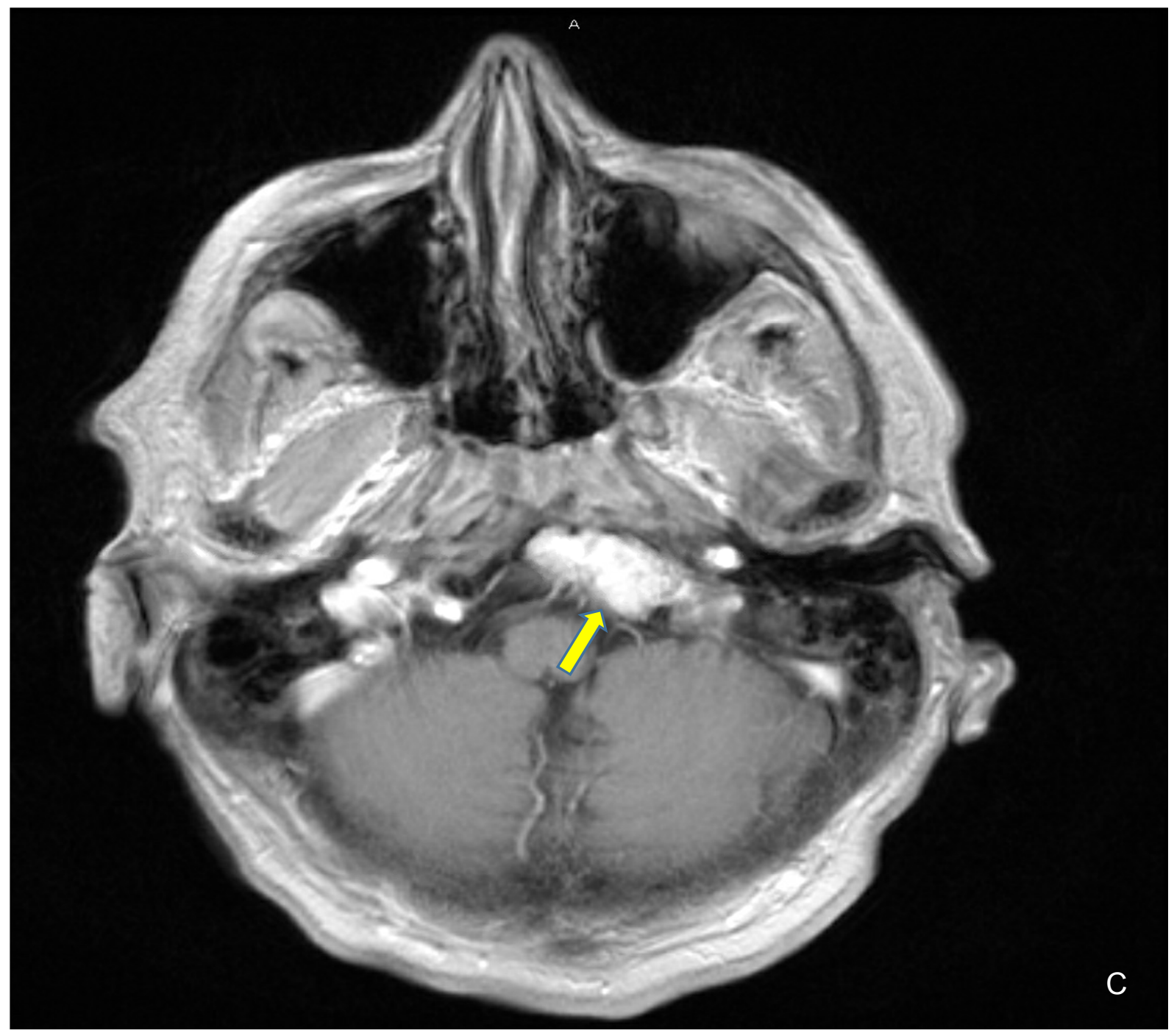


Figure 2. H\&E-stained sections reveal focally preserved osteoid and large areas of bone resorption (A, $100 \mathrm{x}$, measuring bar $=100 \mu \mathrm{m}$ ) characterized by multinucleated osteoclast-like giant cells and fibroblasts (B, 400x, measuring bar $=50 \mu \mathrm{m})$. Multifocal hemosiderin depositions $(C, 400 x$, measuring bar $=50 \mu \mathrm{m})$ represent degenerative changes that commonly occur in brown tumors.
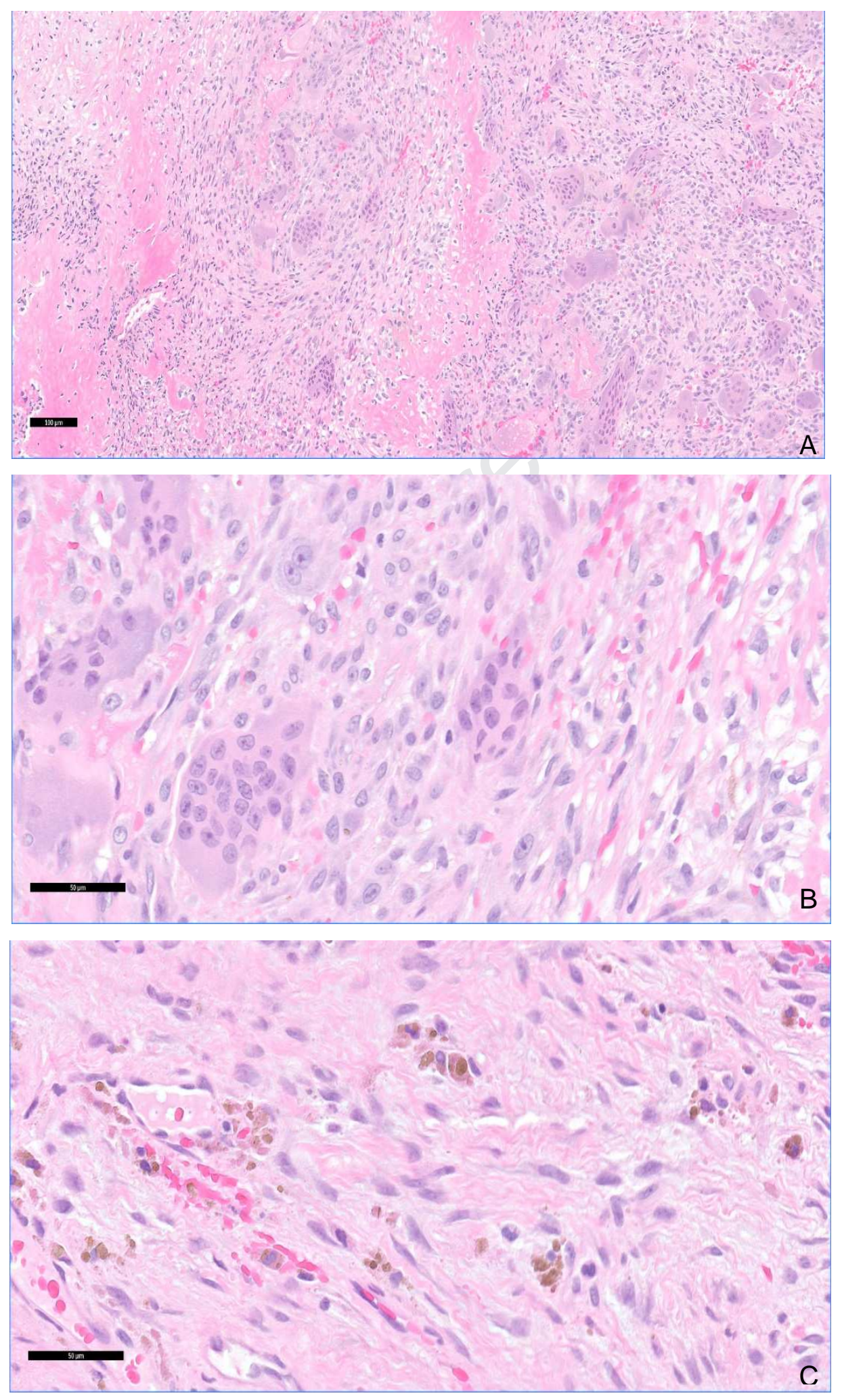
Figure 3. Preferred Reporting Items for Systematic Reviews and Meta-Analyses (PRISMA) flow diagram of article identification and selection.

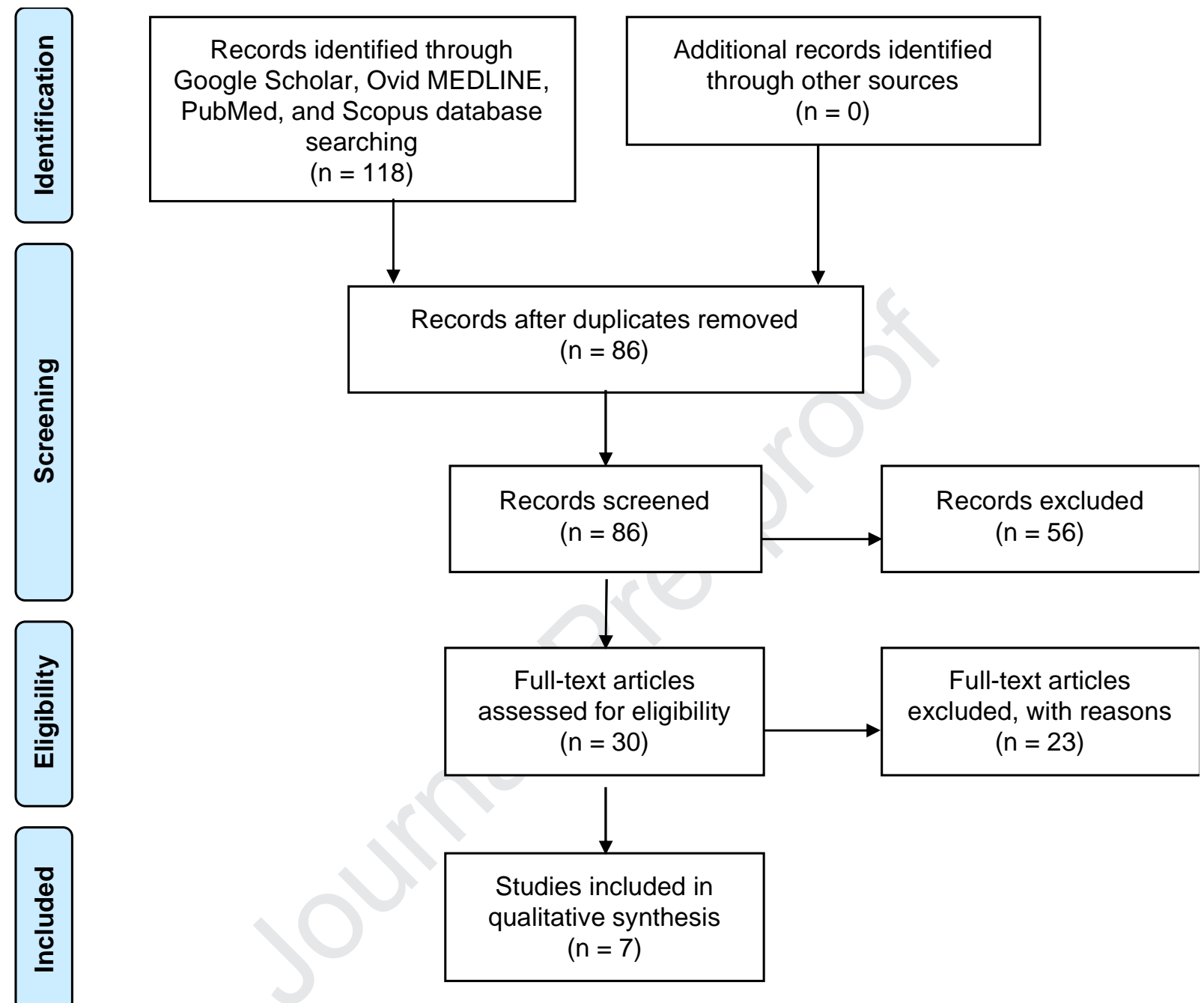




\section{ABBREVIATIONS}

$\begin{array}{lll}\text { ALP } & - & \text { Alkaline Phosphatase } \\ \text { CT } & - & \text { Computed Tomography } \\ \text { ED } & - & \text { Emergency Department } \\ \text { ESRD } & - & \text { End Stage Renal Disease } \\ \text { MRI } & - & \text { Magnetic Resonance Imaging } \\ \text { PRISMA } & - & \text { Preferred Reporting Items for Systematic Reviews and Meta-Analyses } \\ \text { PTH } & - & \text { Parathyroid Hormone } \\ \text { SPECT } & - & \text { Single Photon Emission Computed Tomography }\end{array}$

